\title{
The need for local communities' involvement in the future of real cultural heritage
}

\section{KEYWORDS}

tangible heritage, sustainable development, heritage value, heritage ownership, local community

\begin{abstract}
Aleksandra Ćwik, The need for local communities' involvement in the future of real cultural heritage. Culture - Society - Education no. 2(18) 2020, Poznań 2020, pp. 367-381, Adam Mickiewicz University Press. ISSN 2300-0422. DOI 10.14746/kse.2020.18.13.2.

The discussion about cultural heritage versus development has been touched upon in many publications, and the role of cultural heritage is being deployed increasingly into transforming mere development efforts into efforts for sustainable development. By analysing recent literature which indicates the need for facilitation of cooperation between authorities and local communities, the theory of ownership and value of cultural heritage, and the close relationship between heritage protection and sustainable development, the article aims to discuss the role of the local community in managing monuments. The most relevant conclusions include the link between the protection of cultural heritage and the improvement of the quality of life of residents, their sense of identity and more durable bonds with the place of residence and the strife toward the achievement of local, sustainable development goals.
\end{abstract}

\section{Introduction}

The subject of cultural heritage and development, had already been raised in numerous publications (i.a. Broński, 2006; Murzyn, 2002; Potoczek, 2000; Purchla, 2014), while the essential role of heritage in the already necessary transformation

* ORCID: 0000-0002-5357-6922. 
of efforts in development is increasingly raised, regarding the efforts in development that is balanced, sustainable and present in all three aspects of human functioning in the state, i.e. economy, natural environment, and society (Gorzelak et al., 2018; Janikowski, Krzysztofek, 2009; Nocca, 2017; Purchla, 2000). The following article aims at bringing up the discussion during a moment, when the negative effects of unsustainable development in Poland and worldwide are increasingly noticeable. Through the analysis of current literature, indicating the requirement of the facilitation between local authorities and residents, the theory of property, and the value of cultural heritage, as well as, a strict relationship between the protection of cultural and natural heritage, and sustainable development, the author raises a debate regarding the role of local societies in monument management. Additionally, the article aims at introducing dialogue initiated in a work titled Greater Poland Cultural heritage, in the light of the data provided by the National Heritage Institute. The example of immovable monuments (Dziedzictwo kulturowe województwa wielkopolskiego w świetle danych Narodowego Instytutu Dziedzictwa. Przykład zabytków nieruchomych, Siniecka, Bogacka, 2018).

The outbreak of the COVID-19 pandemic, which took place during the beginning of 2020, led to forced social isolation almost worldwide, and a stream of reflections about the mutual future following the crisis. The results of recession, which becomes an inevitable reality in April 2020, will be experienced for times to follow, however, the social enthusiasm to discard ill habits such as consumerism or deepening social inequalities, is fading gradually. Currently, it is exceptionally important to grasp the momentum, so that the growing human longing for closeness and security may become a factor of change, and not a reason for disappointment. The need for security is not simply a basic longing in the pyramid of human needs, but also it is identified with the requirement for the reduction of noticeable deficiencies (Maslow, 1943). Reminding this, already overused theory, aims at strengthening the message, that actions and development in a trusted environment are motivational for an individual, something of which one should not forget while making a decision regarding promotion of local activism, cultural as well. The knowledge and experience of the creative sector plays an enormous role in communicating and diagnosing collective challenges and motivating for conscious action. Cultural artists and activists possess competencies of evaluation of the social evolution and inspiration for action (Kern, 2020). Additionally, Global Heritage Fund (GHF) reminds that economic activity may, in the future, largely depend on the cultural heritage and the society, which to this moment used to base their source of livelihood on its protection (Global Heritage Fund, 2020). In the case, where the creation of an environment advantageous for the activities of 
local community, is a priority of the local and supra-local cultural policy, the effect is a bright, however not always reproducing traditional solutions, future of immovable national or regional heritage. As noted by Skaldawski (2017), in democratic countries, the awareness and perception of own cultural heritage depends on two equally, and mutually influent factors. Public opinion, the work of activists and passionate individuals, being a part of the aforementioned local societies, and their pressure on authorities, on varying levels, should form decisions regarding heritage maintenance. Similarly, the state, through education and social campaigns, is obligated to form an objective local and national responsibility for cultural heritage.

\section{The subject of discussion}

The arguments presented in the article are based on the definition of heritage by Laurajane Smith (2006), who describes heritage in the broadest aspect, as a process of involving oneself in the past. Involvement, actively taking responsibility, is the core around which the author build her arguments in this paper. Tangible cultural heritage was comprehensibly defined in the first paragraph of the Convention Concerning the Protection of the World Cultural and Natural Heritage (UNESCO, 1972), and will be used in the same way, in the following comparisons ${ }^{1}$.

The National Heritage Board established in 2011, is the primary and comprehensive source of knowledge regarding the state and number of monuments in Poland. The most comprehensive is the Immovable Monuments Register, which contains 78009 records (as of 8 January 20202). As noted by Siniecka and Bogacka (2018) in their profound study on cultural heritage of the Greater Poland Voivodeship, and on the basis of the aforementioned data, isolating particular information regarding each type of an immovable monument, and generating statistics

${ }^{1}$ Art. 1 of the Convention lists the three following elements of cultural heritage: architectural works, works of monumental sculpture and painting, elements and buildings of archaeological nature, writings caves and group of element, which are of outstanding universal value from the point of view of history, art or science; 2 . Groups: of separate or connected buildings which, because of their architecture, their homogeneity or their place in the landscape, are of outstanding universal value from the point of view of history, art or science; 3 . Sites: works of man or the combined works of nature and man, and areas including archaeological sites which are of outstanding universal value from the historical, aesthetic, ethnological or anthropological point of view (UNESCO, 1972).

${ }^{2}$ Source: data presented by the National Heritage Board through: https://dane.gov.pl/dataset/1130. 
using the NHB sources, is incredibly time and work consuming ${ }^{3}$. Additionally, it is worth noting, that the registry is created by means of administrative decisions, which in turn are made "through years, in changing legal, doctrine, organisational, and technical conditions" is very dynamical and inhomogeneous (Brudnicki, 2016). Due to the fact, the data studied by the authors of the "Greater Poland Cultural heritage, in the light of the data provided by the National Heritage Institute. The example of immovable monuments" will serve as representative in the inquiries regarding the need for the involvement of citizens in the protection of immovable heritage (Siniecka, Bogacka, 2018).

According to the authors' conclusions, the monuments in Greater Poland are not spread equally and their quantity and quality spread across the entire voivodeship. Some districts possess a large number of monuments, while some have fewer. The most monuments registered are located in Poznań, and it is 9,26\% out of 6987 on the list, i.e. 647 items; the situation is similar in three wealthy counties, Poznań county (7,27\%, i.e. 508 items), Kościan county (5,41\%, 378), and Gniezno county $(5,17 \%, 361)$. In counties, where the number of monuments is the lowest, Chodzież, Ostrzeszów and Konin counties, one may find 77 monuments on average (Siniecka, Bogacka, 2018:57-58). Further notions regarding the cultural heritage assets in the voivodeship are as follows:

- The density of monuments varies in different counties, where the average is 2,34 monument in 10 square kilometres, with the highest density in cities with county status, including Leszno, Poznań, Kalisz and Konin, in an order, where in Leszno, the monuments are most densely situated (Siniecka, Bogacka, 2018: 57-59).

- The most common monuments, are residential buildings, followed by sacral buildings, greenery, farm buildings and residential complexes. Castles are the least common types of monuments in the Greater Poland Voivodeship (Siniecka, Bogacka, 2018: 59).

- The largest number of monuments in each county, are from the $19^{\text {th }}$ century, fifteen out of thirty five counties also possess the oldest monuments, dated before the second half of the $13^{\text {th }}$ century. Every county includes objects, which lack information regarding their dating (Siniecka, Bogacka, 2018: 62).

3 The national National Heritage Board lists immovable monuments using the following categories: cultural landscape, spatial layout, small architecture, sacral architecture (church, orthodox church, mosque, synagogue, chapel, monastery), defensive architecture (gatehouse, stronghold, defensive wall, castle), industrial architecture (factory, bridge, mine, railroad infrastructure, windmill, mill), park and garden complex (garden, park pavilion, park, alley), residential complex (palace, manor), public building (town hall, bathhouse, inn), utility building, site of remembrance, cemetery, and other. Source: https://zabytek.pl. 
- According to the authors, the origins of differences in the quantity and types of monuments is related to "[...] soil quality, the availability of natural resources, communication and trade lanes, shaping of country borders, local and sacral administration, the emergence of elite centres (including the region capital), functioning of the university or an important cult site [...], the fact that the Greater Poland was under different partitions" (Siniecka, Bogacka, 2018: 60-62).

The qualitative comparison presents an example status of the location and density of monuments in one of Polish regions. However, the quality of monument objects does not always go in line with their value. The fact that a particular region has few monuments, does not mean, that it does not enjoy popularity among tourists, or interest of scholars. The amount and value of monument objects are placed unequally, and are not necessarily dependent on each other, therefore, it is difficult to expect the local government to be involved actively in improving the state of each object within their jurisdiction. Moreover, that the concept of "value" of cultural heritage is an assortment of many factors, with not all of them being objective. The origins of the value of cultural heritage may be divided into relative, i.e. those which are dependent on certain dynamic norms accepted in particular societies, and universal, i.e. objective and indisputable within cultural norms.

Table 1. Comparison of elements amounting to evaluating value of cultural heritage objects

\begin{tabular}{|l|l|}
\hline \multicolumn{1}{|c|}{ Relative perception of cultural heritage value } & Universal perception of cultural heritage value \\
\hline $\begin{array}{l}\text { Aesthetic aspect } \\
\text { A subjective evaluation of beauty, individual aes- } \\
\text { thetic experience of each recipient. }\end{array}$ & $\begin{array}{l}\text { Financial aspect } \\
\text { Assumes, that heritage is a form of goods, and that } \\
\text { monuments posses certain monetary value on the } \\
\text { potential market. }\end{array}$ \\
$\begin{array}{l}\text { Symbolical and association aspect } \\
\text { Related to history, cultural traditions and norms of } \\
\text { particular societies. It influences the strengthening } \\
\text { of patriotic attitudes, cultural or national identity, } \\
\text { or the feeling of responsibility for local traditions } \\
\text { or place of residence. }\end{array}$ & $\begin{array}{l}\text { Assumes, that heritage in a form of e.g. historical } \\
\text { objects, may be used (consumed) both currently } \\
\text { and in the future. } \\
\text { Symbolical aspect } \\
\text { Assumes, that heritage is valuable not due to eco- } \\
\text { nomic reasons, but as a value in itself, as the cultu- } \\
\text { ral capital of the entire mankind. } \\
\text { Artistic aspect } \\
\\
\text { Not subjective, but based on scientific evaluation } \\
\text { of certain artistic skill. Based on formal evalua- } \\
\text { tion. }\end{array}$ \\
\hline
\end{tabular}

Source: Kobyliński, 2011. 
According to the comparison (Table 1) of the factors contributing to the perception of historical monuments regarding their value, therefore, their influence on recipients, there are many elements included. However, not every element is essential for each group of recipients, which suggests a question, to whom the heritage belongs, and within the context of this paper, the more important question should be "to whom the monuments in my region belong?".

One of ways to analyse this complicated situation of the property of objects registered as monuments, therefore, the understanding where the direct responsibility over monuments in Poland is placed, is to collect data of applicants for funding of conservatory works. Below (Table 2), we present the data shared by the Ministry of Culture and National Heritage (Ministerstwo Kultury i Dziedzictwa Narodowego - later referred to as MKiDN) in the form of enrolments for funding within the MKiDN 2019 "Monument Conservation" programme. The primary aim of the given funding is essential, as included in the statute as "preserving material cultural heritage, realised through conservation and revaluation of immovable and movable monuments, and sharing them for public aims"4.

Table 2. Analysis of applicants for the support regarding monument preservation from the MKiDN

budget, within the "Monument Conservation" programme for 2019. According to the statute, the programme budget amounts to $112125000 \mathrm{zl}$, while the sum of funding provided during both enrolments is $135432952 \mathrm{zt}^{5}$.

\begin{tabular}{|l|r|r|r|r|r|r|r|r|}
\hline Applicant & \multicolumn{2}{|c|}{ Private applicant $^{6}$} & \multicolumn{2}{|c|}{ State institutions } & \multicolumn{2}{|c|}{$\begin{array}{l}\text { Church institu- } \\
\text { tions }\end{array}$} & \multicolumn{2}{|c|}{$\begin{array}{c}\text { Sum (Including } \\
\text { accepted applica- } \\
\text { tions) }\end{array}$} \\
\hline Enrolment & $\begin{array}{l}\text { Enrol- } \\
\text { ment I }\end{array}$ & $\begin{array}{l}\text { Enrol- } \\
\text { ment II }\end{array}$ & $\begin{array}{l}\text { Enrol- } \\
\text { ment I }\end{array}$ & $\begin{array}{l}\text { Enrol- } \\
\text { ment II }\end{array}$ & $\begin{array}{r}\text { Enrol- } \\
\text { ment I }\end{array}$ & $\begin{array}{l}\text { Enrol- } \\
\text { ment II }\end{array}$ & $\begin{array}{l}\text { Enrol- } \\
\text { ment I }\end{array}$ & $\begin{array}{r}\text { Enrol- } \\
\text { ment II }\end{array}$ \\
\hline $\begin{array}{l}\text { Number of } \\
\text { application } \\
\text { submitted } \\
\text { (percentage) }\end{array}$ & 286 & 131 & 219 & 125 & 1299 & 379 & 1804 & 635 \\
$(15,9 \%)$ & $(20,6 \%)$ & $(12,1 \%)$ & $(19,7 \%)$ & $(72 \%)$ & $(59,7 \%)$ & $(530)$ & $(87)$ \\
\hline
\end{tabular}

${ }^{4}$ Souirce: MKiDN, Program MKiDN 2019, Monument Conservation, Enrolment Results with Appeals XLS, and Enrolment Results II with Appeals XLS, available under the following link: http:// www.mkidn.gov.pl/pages/strona-glowna/finansowanie-i-mecenat/programy-ministra/programy-mkidn-2019/ochrona-zabytkow.php.

${ }^{5}$ Ibid.

${ }^{6}$ Including private enterprise, individuals, cooperatives and communities, as well as, funds and enterprises which are renters of a monument belonging to the local government, e.g. a district. Therefore, the table presents the owners and subjects responsible for monuments. In the case, when a state institution is an owner, and an individual or a private enterprise is the renter, the priority is given to the renter as the subject with direct responsibility and involvement in the object's protection.

${ }^{7}$ Including local government institutions and public cultural institutions such as museums, libraries, theatres or houses of culture. 
Regardless of the variety of subjects that manage heritage actively, therefore, those responsible for the preservation of objects, including applying for funds for conservation, or sharing them for public aims, it is difficult to discuss regarding monument property. One of the reasons is presented in Table 1, the relative aspect of establishing the value of monument objects. Heritage is the more valuable, the larger the society, which it influences. Therefore, as Kobyliński notes in his considerations regarding cultural heritage property (2011: 41); “Therefore, the issue of cultural heritage property is not a legal problem (despite the fact that attempts are made to resolve it on legal grounds), but an ethical one. From the viewpoint of the cultural development of mankind it is not important, who possesses the matter of cultural heritage, but who, and in what way, has the right to take advantage of its non-material values".

\section{The need for involvement of the local society}

Often, the involvement of local society in common life, or a relatively substantial knowledge regarding the surroundings, or the urge to acquire additional knowledge, are the primary determinants affecting the strengthening of psycho-social bonds of residents with their place of residence (Michalska, 2002). Moreover, the level of mobilisation in districts, i.e. active and inflicting bottom-up pressure residents, motivate the local authorities to self-development in the areas of management and innovation, so that they may respond to the actions of non-government organisations, competing political parties or local media (Hryniewicz, 2004: 68). In a similar spirit, out of the initiative of the Finnish branch of Europa Nostra (EuNoF), in 2018, a paper was published, titled Heritage is Ours. Presenting good practices and examples, when the residents actively influenced the administrative decisions regarding their local heritage, the authors divided types of residents' participation in two groups, regarding the origins of initiatives.

According to the largely simplified distinction, the first group is assorted of bottom-up initiatives, while the second is assorted of administrative bodies, top-bottom but not forced. The primary premise of the promotion of residents collaborating with local authorities, is mutual listening to postulates and cooperation that is not based on hierarchy. The instruments for such sustainable collaboration are place mapping and cultural planning] (Halme et al., 2018). Ghilardi (2018) presents both instruments as essential in the new movement of space planning, based on a system of relations, individual for every - in the context of his research city. An example of a successful implementation of the method, within the context of the protection and promotion of regional cultural heritage is Czech Zlin. 
Due to the collaboration with the university, the regional chamber of commerce and local representatives of creative industry, a strategy was created, resulting in the transformation of the neglected industrial heritage, which - associating creative companies that specialise in design and new technologies - had become the region's flagship (Ghilardi, 2018: 106). Practical instruments, by which the author is demonstrating her approach to planning the future of space, including cultural heritage, and which are based on the unique cultural DNA of a particular location, are i.a.:

1. Analysis of secondary sources, including existing plans and strategies, as well as, data regarding the state of economy of a location, and local methods of governance.

2. Mapping the exceptional quality of the location, the narrative of the location, and the way the location is being experienced.

3. Social identity mapping, including the current industrial and economic dynamics, types of competencies among residents, models of relations between residents, the level of cultural diversity and lifestyle, as well as, level of education.

4. Mind mapping, including the work on new social policies, learning and development on case studies, and good practices from other cities, support for implementing non-standard mechanisms of creative management.

5. Qualitative mapping of local cultural and creative resources, including diagnostics of the value chain in creative industries, cluster mapping, evaluation of cultural and recreation infrastructure, evaluation of cultural activity and diversity, evaluation of cultural consumption and active participation (Ghilardi, 2018: 105).

Mobilisation or allowing participation to the residents, regarding planning of using or preserving monuments, has - apart from the aforementioned effects, such as the feeling of agency and stronger bonds with place of residence - also other consequences, with which the specialists in terms of cultural heritage in Great Britain and the United States had learned to cope. The involvement of residents in decision making allows for a more just and reasonable negative selection, which is a necessity (Kobyliński, 2011: 26). Research conducted in 2017 by the NID and the Jagiellonian University Institute of Sociology, within the scope of the DoM Dziedzictwo obok Mnie (HoMe - Heritage on $\mathrm{Me}$ ) project, allowed for a qualitative overview of the attitude of the Poles towards heritage. The results may be considered as promising, because, despite differences in age, and education of the respondents, a distinct majority of them feels the necessity of cultural heritage in the life of their own society and the entire nation. For example, $85,3 \%$ of respondents 
considered cultural heritage as important for Poland as a society, and $77,2 \%$ for local societies. Moreover, $89,7 \%$ Poles perceive cultural heritage as a factor which makes their place of residence exceptional. No clear differences were noted regarding how city and rural residents perceive the influence of heritage on the quality of life of local societies, a vast majority of answers was affirmative (82,6\% in rural areas, $89,2 \%$ in cities below 50 thousand residents, $77,5 \%$ in cities between 50 and 200 thousand residents, and $90 \%$ in cities with more than 200 thousand residents) (Fortuna-Marek, Stępnik, 2017: 25-29).

\section{Cultural heritage and sustainable development}

At the moment of a pandemic with ongoing far-fetched consequences, which is not a result of climate change and its growing challenges - is it worth to delegate time and energy for a discussion about the preservation of the witnesses of the past in such condition? Articulating an important role of the preservation of local heritage is crucial here - which is not necessarily divided into natural and cultural, but often occurs as an indivisible fusion of both forms - fighting for a stable future.

For the needs of the considerations below, the author will be using the definition of "sustainable development" formulated in 1987 by the World Commission on Environment and Development, in a report titled Our Common Future . The $^{8}$ so-called "Brundtland Commission" assumes that the current generation should strive for improving the natural environment, as well as, the social and economic situation in a way, so that the achieved status would become an established and immutable norm. Sustainable development is equal supply for human needs worldwide, in a way, that it does not rob future generations from the very same natural and cultural resources, which are being used currently (Nocca, 2017; ONZ, 1987).

A decade has passed since the crucial paper in this matter, published by the UNESCO Polish Commission, titled Culture and Sustainable Development (Janikowski, Krzysztofek, 2009), however, many postulates included were not accomplished. Examples are as follows: the need for education regarding space aesthetics (Krzysztofek, 2009: 45) which, when at a high level, positively influences the competitiveness of regions both in the perception of their residents, as well as, outsiders; or the already mentioned necessity to protect cultural and natural environment as a whole, in an integrated way (Myczkowski, 2009: 65-86). Based on

\footnotetext{
8 The report is available in English: United Nations, 1987. Our Common Future: Report of the World Commission on Environment and Development - Brundtland Report; United Nations: New York, NY, USA, http://www.un-documents.net/our-common-future.pdf.
} 
UNESCO documents such, important in the matter, Convention on protection and promotion of the diversity of cultural expressions (written in 2005, and ratified by Poland in 2007) publication, was created for i.a. the promotion of culture as an essential factor in state development and a building block of democracy. Due to cultural diversity and strong cultural identity of the society, it is made possible to oppose the negative effects of globalisation, which may be contrary to the idea of sustainable development. For example, as noted by Krzysztofek (2009: 58) "Only in regions and societies with strong cultural identity (as in Podhale) regional habits regarding food prevailed, not only due to promotion, but also due to everyday life". Therefore, local enterprise may flourish, while the society, which avoids fast food restaurants, is healthier.

Material and non-material heritage, including buildings, landscapes, or traditions and customs is directly formed by historical narrative and national myths. A collage unique for every nation and society, a mixture of tradition and tangible heritage creates something that Genevieve Zubrzycki (2017: 193-195) calls national sensorium, which allows citizens to actually feel and associate with the concept of nationality which, according to the author, would be just but an abstract without sensorium. Simultaneously, tangible heritage is one of the most conventional expressions of local culture, which, as noted by Broński (2006) may function as a flagship of the region, or a tourist attraction, and therefore, positively influence the economic development of the little "homeland". Moreover, tourism in Central Europe has potential to attract tourists abroad. Hence, the great advantage of cultural tourism appears, i.e. it accompanies learning, and sightseeing - promotion in terms of tourists from abroad (Kozak, 2009: 78-79). However, not every monument or location with substantial historical and cultural value is appealing enough to attract tourists and not every one of them should be open for sightseeing for so long, to not only cover the expenses of maintenance but also support the local economy. In other words, which also appeared in the work by Bojańczyk (2019), some historical monuments are forced to earn their keep and future, while "[...] It could be covered by state patronage, which would take essential heritage out of market rules, which led e.g. to the organisation of paintball fights in the Wolf's Lair".

In order to combine the above considerations with the aforementioned definition of the "Brundtland Commission" sustainable development, it is worth to recall examples where neglecting cultural heritage was an irreversible mistake in the historical perspective, as well as, the currently disputed space, where protection and preservation of culture intertwines with environmental protection. In 1980, the American company General Motors, managed to persuade Detroit authorities to hand over the entire lot located at the border area of the city, and the suburbs, 
officially known as Hamtramck, and unofficially known as "Poletown". Despite the active protests by the residents, exactly 1500 homesteads, 144 small businesses, and 16 churches, all constructed and maintained by the Polish community, were demolished in order to give space for the new GM automobile factory. In November 2018, the last of the two factories was closed, and more than 1500 people lost employment. Currently, Detroit authorities are considering whether the demolition of Poletown brought the desired results, i.e. introducing innovation and economic expansion of the region. Amy Crawford (2018) indicates the number summary of the results of the relocation of residents. Prior to 1980, the location gave employment to 4200 residents. They mostly dealt in small business, which mostly operated in the same place since the $20^{\text {th }}$ century. The factory building, which is waiting to be facilitated as a heritage monument, was a location for 3000 employees (Crawford, 2018). Here, a remark must be made, that the example was brought upon not due to the origins of the residents, but as a direct example of actions which led to the necessity of redefining the concept of sustainable development.

Similarly, however, the issue raised is related to a larger scale, neglecting the Polish wooden architecture should be treated. Losses are mostly related to small architecture, residential and public architecture, as, i.a. due to the records on the UNESCO World Heritage Site (six wooden churches in Lesser Poland and in Podkarpacie, submitted in 2003), sacral architecture enjoys worldwide reputation and popularity among tourists. This includes i.a. the wooden churches of Sląsk Opolski ${ }^{9}$. However, as we read in the paper titled Wooden treasure. Protecting the heritage, we create the future (Drewniany Skarb. Chroniac dziedzictwo, kreujemy przyszłośc) , "At the current moment, the traditional wooden construction is fading into obscurity. Windmills, watermills, forges, inns, wooden buildings in farms are a scarcity. Therefore, there is a need to describe and save, what can be saved. Each preserved wooden object is not only a testament of traditional wooden construction, but also a source of knowledge about the customs, culture and the history of regions and nations" (Pietrasiewicz, 2016: 8). Afterwards, we learn about the role of ambassadors for wooden heritage protection: "[...] we demonstrate the function wood fulfilled, and may still fulfil in Polish architecture of the time. We present an astonishing variety and harmony of wooden architecture with the natural environment. We pursue the answer to a question, where the unique character of wooden houses and the charm of small towns with their wooden structure came from" (Pietrasiewicz, 2016: 9).

\footnotetext{
${ }_{9}$ Presentation of the churches in the form of a virtual collection was created by the National Heritage Board and presented via the zabytek.pl. Portal zabytek.pl, https://zabytek.pl/pl/kolekcje/ koscioly-drewniane-slaska-opolskiego.
} 
In response to Lowenthal's (1998) observations, that there is no aspect of nature, that the activity of man would not influence, and that there is no object, on which nature would not leave its mark, one may easily state that cultural heritage preservation is in line with natural heritage preservation. The negative influence of climate change on the national heritage was demonstrated empirically. Moreover, too often, the most vulnerable societies are those who contribute to the emissions of greenhouse gases the least. Additionally, in turn, recent reports indicate a positive influence in a different direction. Protection and promotion of cultural heritage allows to stop the climate crisis effects in a practical way, i.a. by propagating circular economy, renovation and restoration of buildings in order to avoid new constructions, using local materials with low carbon footprint, and indigenous solutions and technologies (ICOMOS, 2019; KE, 2019). Eventually, in April 2020, Europa Nostra, i.e. the European organisation established to support civic society in heritage protection, along with ICOMOS (The International Council on Monuments and Sites), began actions for including the protection of cultural heritage in the premises of the ambitious European Green Deal (EGD) plan ${ }^{10}$. The planned publication titled European Heritage Green Paper is to turn attention of its creators to the need to supplement EGD - the primary aim of which is to maintain global growth of temperature at 1,5 Celsius - with the cultural heritage aspect (Europa Nostra, 2020) ${ }^{11}$.

\section{Summary}

The aim of the aforementioned considerations was the analysis of the involvement of residents in making decisions regarding the future of monuments present within their proximity. Among the most important notions, is the link between cultural heritage preservation, with improving the life quality of the residents, their feeling of identity, and the bond with their place of residence, as well as, with achieving local aims of sustainable development. Moreover, accepting the non-hierarchical collaboration with the local society, leads to sustainable spatial planning and cre-

10 The aims of the new policy promoted as European Green Deal are available on a dedicated portal of the European Commission, https://ec.europa.eu/info/strategy/priorities-2019-2024/european-green-deal_en.

${ }_{11}$ Within these considerations, a fact is important, that Europa Nostra is a member of the Climate Heritage (http://climateheritage.org/) network, which was established in order to facilitate and support the actions of its active members within the scope of cultural heritage protection, for achieving the aims of the 2015 Paris Agreement. 
ating efficient strategies for regions. Ultimately, encouraging residents to actively participate is a serious task for the authorities, as it should be present in education, social campaigns and day-to-day consultations. It is a task which, in a long term perspective, may yield positive results in form of equally placed responsibility in regard to the cultural heritage of regions, and the affection of the residents towards their place of residence, which, in their perception, is competitive and where they feel safe.

\section{Bibliography}

Bojańczyk F. (2019), Polskie dziedzictwo, czyli jak sensowniej zarządzać naszymi zabytkami. Ablogeracja. O mieście, Europie Środkowej i dziedzictwie, http:// ablogeracja.pl/?m=201912.

Broński K. (2006), Rola dziedzictwa kulturowego w rozwoju lokalnym. Doświadczenie polskie doby transformacji (po 1989 r.), „Zeszyty Naukowe Akademii Ekonomicznej w Krakowie”, no. 706, pp. 7-26.

Brudnicki J. (2016), Stwierdzenie nieważności decyzji o wpisie do rejestru zabytków, „Ochrona Zabytków", no. 2, pp. 69-104, http://cejsh.icm.edu.pl/cejsh/element/bwmeta1.element.desklight903e9701-5e71-406a-b8a2-8aa7c472feb6.

Crawford A. (2018), Can Poletown Come Back After a General Motors Shutdown?, https://www. citylab.com/equity/2018/12/poletown-history-general-motors-hamtramck-shutdown/577678/.

Europa Nostra (2020), Collaboration launched on a "European Heritage Green Paper", https://www. europanostra.org/collaboration-launched-on-a-european-heritage-green-paper/.

Fortuna-Marek A., Stępnik K. (2017), Komponenty postaw Polaków wobec dziedzictwa kulturowego, in: Dziedzictwo kulturowe w badaniach. Polacy wobec dziedzictwa. Raport z badań społecznych, vol. 1, eds. A. Chabiera, A. Dąbrowski, A. Fortuna-Marek, A. Kozioł, M. Lubaś, P. Nowak, B. Skaldawski, K. Stępnik, Warszawa-Kraków.

Global Heritage Fund (2020), Heritage is Hope in a Time of Crisis, https://globalheritagefund. org/2020/03/17/heritage-is-hope-in-a-time-of-crisis/.

Gorzelak G., Rok J., Wojnar K. (2018), Ku zrównoważonemu rozwojowi polskich miast, „Przegląd Polskiego Komitetu do spraw UNESCO”, pp. 69-81.

Halme A., Mustonen T., Taavitsainen J., Thomas S., Weij A. (2018), Heritage is Ours. Citizens Participating in Decision Making, Helsinki.

Hryniewicz J. (2004), Polityczny i kulturowy kontekst rozwoju gospodarczego, Warszawa.

International Council of Monuments and Sites ICOMOS (2019), Climate Change and Cultural Heritage Working Group. 2019. The Future of Our Pasts: Engaging Cultural Heritage in Climate Action, https://indd.adobe.com/view/a9a551e3-3b23-4127-99fd-a7a80d91a29e.

Janikowski R., Krzysztofek K. (eds.) (2009), Kultura a zrównoważony rozwój. Środowisko, ład przestrzenny, dziedzictwo, Warszawa.

Kern P. (2020), Artists and culture to imagine the way out of the crisis, https://keanet.eu/artists-andculture-to-imagine-the-way-out-of-the-crisis/.

Kobyliński Z. (2011), Czym jest, komu jest potrzebne i do kogo należy dziedzictwo kulturowe?, „Mazowsze. Studia Regionalne. I. Analizy i Studia”, no. 7, pp. 21-46. 
Komisja Europejska (2019), Natural and Cultural Heritage in Europe: Working Together within the Natura 2000 Network, https://ec.europa.eu/environment/nature/natura2000/management/pdf/ Natural_and_Cultural_Heritage_report_2019_WEB.pdf.

Kozak M. (2009), Turystyka i polityka turystyczna a rozwój: między starym a nowym paradygmatem, Warszawa.

Krzysztofek K. (2009), Kapitał przyrodniczo-kulturowy Polski jako zasób zrównoważonego rozwoju, in: Kultura a zrównoważony rozwój. Środowisko, ład przestrzenny, dziedzictwo, eds. R. Janikowski, K. Krzysztofek, Warszawa.

Lowenthal D. (1998), The Heritage Crusade and the Spoils of History, Cambridge.

Maslow, A.H. (1943), A Theory of Human Motivation, „Psychological Review”, no. 50 (4), pp. 370-396.

Michalska A. (2002), Psychospołeczne więzi z miejscem zamieszkania na przykładzie wybranych osiedli łódzkich i wsi Brudzewice, „Studia Regionalne i Lokalne”, no. 1 (8), pp. 79-100.

Ministerstwo Kultury i Dziedzictwa Narodowego (2019), Programy Ministra 2019. Ochrona zabytków, http://www.mkidn.gov.pl/pages/strona-glowna/finansowanie-i-mecenat/programy-ministra/programy-mkidn-2019/ochrona-zabytkow.php.

Murzyn M. (2002), Dziedzictwo kulturowe a rozwój miasta, „Zeszyty Naukowe AE w Krakowie”, no. 587 , pp. $65-80$.

Myczkowski Z. (2009), O potrzebie zintegrowanej ochrony środowiska kulturowego i przyrodniczego, in: Kultura a zrównoważony rozwój. Środowisko, ład przestrzenny, dziedzictwo, eds. R. Janikowski, K. Krzysztofek, Warszawa.

Narodowy Instytut Dziedzictwa (2020), https://dane.gov.pl/dataset/1130.

Nocca F. (2017), The Role of Cultural Heritage in Sustainable Development: Multidimensional Indicators as Decision-Making Tool, „Sustainability”, no. 9, pp. 1-28.

Organizacja Narodów Zjednoczonych (1987), Our Common Future: Report of the World Commission on Environment and Development - Brundtland Report, http://www.un-documents.net/ our-common-future.pdf.

Pietrasiewicz T. (2016), Drewniany Skarb. Chroniąc dziedzictwo, kreujemy przyszłość, in: Drewniany Skarb. Chroniąc dziedzictwo, kreujemy przyszłość, Ośrodek „Brama Grodzka -Teatr NN”, Lublin.

Potoczek A. (2000), Dziedzictwo historyczno-kulturowe jako czynnik rozwoju lokalnego i regionalnego, in: Instytucje kulturalne i stowarzyszenia regionalne $w$ nowych warunkach rozwoju społeczno-gospodarczego Polski. Materiały z konferencji przedkongresowej, ed. S. Kunikowski, Włocławek.

Purchla J. (2000), Dziedzictwo a rozwój, in: Dziedzictwo a rozwój. Doświadczenie Krakowa, Międzynarodowe Centrum Kultury, Kraków.

Purchla J. (2014), Dziedzictwo kulturowe a kapitał społeczny, in: Dlaczego i jak w nowoczesny sposób chronić dziedzictwo kulturowe?, ed. A. Rottermund, Warszawa.

Skaldawski B. (2017), Problematyka definicji dziedzictwa, in: Dziedzictwo kulturowe w badaniach. Polacy wobec dziedzictwa. Raport z badań społecznych, vol. 1, eds. A. Chabiera, A. Dąbrowski, A. Fortuna-Marek, A. Kozioł, M. Lubaś, P. Nowak, B. Skaldawski, K. Stępnik, Warszawa-Kraków.

Siniecka A., Bogacka E. (2018), Dziedzictwo kulturowe województwa wielkopolskiego w świetle danych Narodowego Instytutu Dziedzictwa, „Przykład Zabytków Nieruchomych. Rozwój Regionalny i Polityka Regionalna", no. 44, pp. 53-66.

Smith L. (2006), Uses of Heritage, Routledge (e-book). 
UNESCO (1972), Konwencja w sprawie ochrony światowego dziedzictwa kulturalnego i naturalnego, https://www.unesco.pl/fileadmin/user_upload/pdf/Konwencja_o_ochronie_swiatowego_dziedzictwa.pdf.

Zubrzycki G. (2017), Traces and Steps: Expanding Polishness through a Jewish Sensorium, in: National Matters. Materiality, Culture and Nationalism, ed. G. Zubrzycki, Stanford. 
